\title{
FEEDING STRATEGY OF THE NIGHT SHARK (CARCHARHINUS SIGNATUS) AND SCALLOPED HAMMERHEAD SHARK (SPHYRNA LEWINI) NEAR SEAMOUNTS OFF NORTHEASTERN BRAZIL
}

\author{
Teodoro Vaske Júnior ${ }^{1 *}$; Carolus Maria Vooren ${ }^{2}$ and Rosangela Paula Lessa ${ }^{I}$
}

${ }^{1}$ Universidade Federal de Pernambuco - Departamento de Pesca e Aquicultura/DIMAR (Av. Dom Manuel de Medeiros s/n, 52171-900 Recife, PE, Brasil)

${ }^{2}$ Universidade Federal do Rio Grande - Departamento de Oceanografia

Laboratório de Elasmobrânquios e Aves Marinhas

(Caixa Postal 474, 96201-900 Rio Grande, RS, Brasil)

*Corresponding author: vaske@ig.com.br

\begin{abstract}
A B S T R A C T
A total of 425 stomachs of night shark (Carcharhinus signatus), and 98 stomachs of scalloped hammerhead shark (Sphyrna lewini), from longline and surface gillneters near seamounts off northeastern Brazil, were analysed between 1992 and 1999. Both predators prey upon reef and benthopelagic fishes, migrant cephalopods and deep water crustaceans, showing similar feeding niches (Schoener Index $\mathrm{T}=0.75$ ). The great prey richness of the diets may reflect the fact that the marine food web for these species is very extensive in this region. Due to the concentration for feeding of both predators in the seamounts, intense fisheries should be monitored to avoid localised depletions.
\end{abstract}

\section{RESUMO}

Um total de 425 estômagos de tubarão-toninha (Carcharhinus signatus) e 98 estômagos de tubarãomartelo-entalhado (Sphyrna lewini), oriundos da pesca de espinhel e pesca com rede de emalhe nas adjacências dos bancos oceânicos do nordeste do Brasil, foi analisado entre 1992 e 1999. Ambas as espécies predam sobre peixes bento-pelágicos e recifais, cefalópodes migradores, e crustáceos de águas profundas, apresentando nichos alimentares similares (Índice de Schoener T=0.75). A alta riqueza de presas nas dietas deve ser um reflexo de que as teias alimentares para estas espécies são consideravelmente longas nessa região. Devido à concentração alimentar de ambos predadores nos bancos oceânicos, a pescaria intensa deve ser monitorada para evitar depleções locais.

Descriptors: Feeding aggregations, Seamounts, Carcharhinus signatus, Sphyrna lewini.

Descritores: Agregações alimentares, Montes submarinos, Carcharhinus signatus, Sphyrna lewini.

\section{INTRODUCTION}

The night shark Carcharhinus signatus and the scalloped hammerhead shark Sphyrna lewini are the main elasmobranch species captured in the adjacencies of the seamounts off northeastern Brazil.

C. signatus is a common semi-oceanic carcharhinid found along the outer continental and insular shelves of the tropical and warm temperate Atlantic (COMPAGNO, 1984), being the commonest Carcharhinus in the Brazilian shelf breaks (GADIG; MOREIRA JUNIOR, 1992; SOTO, 2001). According to HAZIN et al. (1990), the main captures of $C$. signatus are made westward of $35^{\circ} \mathrm{W}$ in the area, while the blue shark (Prionace glauca) is the most abundant species east of it. The occurrences of $C$. signatus are closely related to shallow seamounts, where a high CPUE (Catch per Unit of Effort) is obtained (HAZIN et al., 1990; MENNI et al., 1995), being the most important elasmobranch species in the seamount area being found in up to $90 \%$ of catches (SANTANA et al., 2006). In Brazilian waters, the preferencial distribution of $C$. signatus ranges between 20 and 500 $\mathrm{m}$ depths (SOTO, 2001). In the last decade, $C$. signatus changed from being a by-catch of semioceanic longliners to being a direct target species, due to increases in the value of their meat and fins, in areas of relatively large abundance around seamounts (HAZIN et al., 2000). Only recent studies have been carried out on $C$. signatus in northeastern Brazil, the first report on this species in the region having been undertaken by Menni et al. (1995), followed by studies on its reproductive biology (HAZIN et al., 2000), age determination and growth (SANTANA; LESSA, 2004), and on total mercury contamination (FERREIRA et al., 2004). The species' feeding habits are still unknown. 
Similarly, S. lewini is a semi-oceanic species distributed throughout tropical and temperate oceans (COMPAGNO, 1984). As from 1996 several vessels of the northeastern oceanic fleet have employed surface monofilament gillnets and, as a result, the proportion of $S$. lewini in the total oceanic captures has increased from $0.05 \%$ to $13 \%$ of the total catch (HAZIN et al., 2001). In Brazilian waters, $S$. lewini is found along the coast, including the Fernando de Noronha Archipelago, with distribution ranging between 10 and $40 \mathrm{~m}$ depth, extending out to the shelf break (SOTO, 2001). Aspects of reproductive biology have been studied in this region by HAZIN et al. (2001). The species is also found in the Saint Peter and Saint Paul Archipelago, where there is a local longline fishery targeting S. lewini, C. falciformis and tunas (OLIVEIRA et al., 1997; VASKE JUNIOR et al., 2005). The feeding habits of S. lewini are normally reported for young specimens (CLARKE, 1971; BUSH; HOLLAND, 2002; BUSH, 2003; BRUYN et al., 2005; TORRES-ROJAS et al., 2006) due to the ease of obtaining large samples in the beach and coastal fisheries, where individuals between 50 and $130 \mathrm{~cm}$ are captured. However, there is little information concerning the larger individuals that are captured around seamounts.
The aim of the present study is to provide supplementary information on the feeding habits and similarities of the diets of $C$. signatus and S. lewini in the adjacencies of seamounts off northeastern Brazil, and as a complementary study to ascertain their population dynamics, thus initiated for both these species in this region of the Atlantic.

\section{Material AND Methods}

The study area is located between $35^{\circ} \mathrm{W}$ and $40^{\circ} \mathrm{W}$, and $0^{\circ}$ and $05^{\circ} \mathrm{S}$ (Fig. 1). Sampling was carried out between 1992 and 1999, where sharks were collected from fishing vessels that operate longline and drifting gillnets. The longline used consisted of a multifilament mainline with secondary lines attached in cluster of six or seven hooked lines. Fishing operations began about 02:00 hours and ended at dawn. The baits used were Brazilian sardine (Sardinella brasiliensis) and occasionally flying fish (Cypselurus cyanopterus). Drifting gillnets have a stretched mesh of 17 to $30 \mathrm{~cm}$, are $12 \mathrm{~m}$ in depth, and 1 to $7 \mathrm{~km}$ in length. The fishing activity was conducted in the vicinity of the shallow seamounts (between 45 and $230 \mathrm{~m}$ depths) off the States of Ceará and Rio Grande do Norte, more precisely on the banks of Aracati, Guará and Sírius.

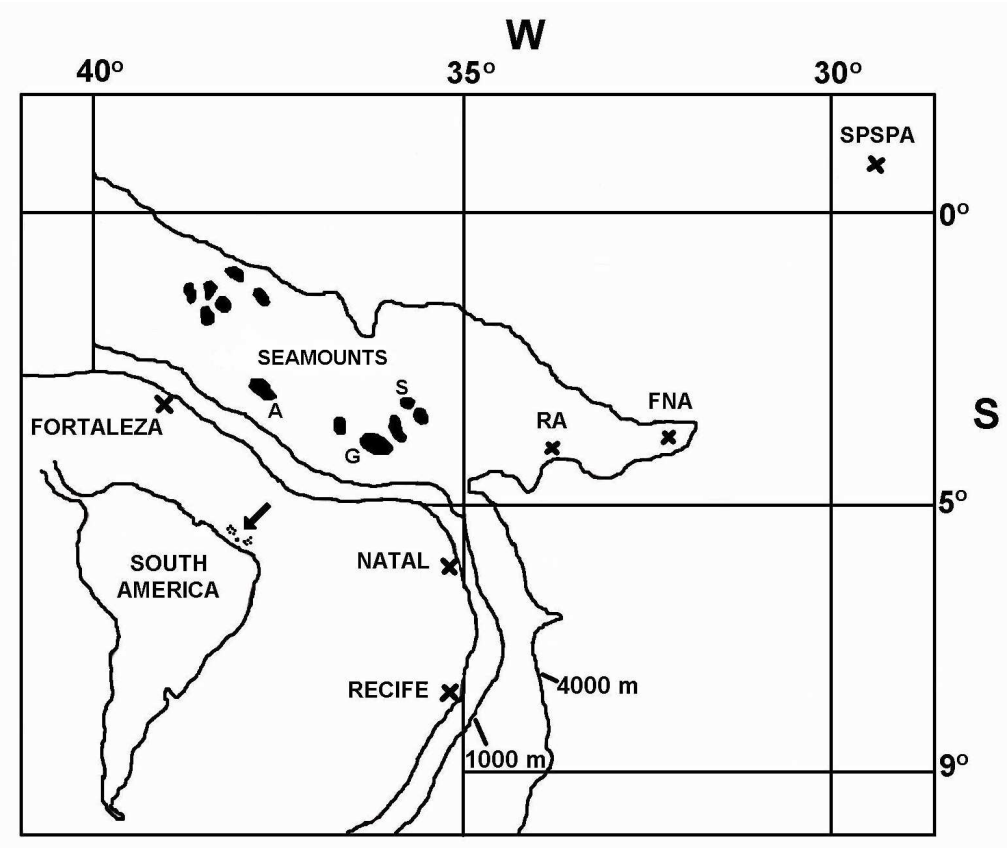

Fig. 1. Main seamounts off northeastern Brazil. A - Aracati; G - Guará; S Sirius; RA - Rocas Atoll; FNA - Fernando de Noronha Archipelago; SPSPA Saint Peter and Saint Paul Archipelago. Isobaths of 1000 and $4000 \mathrm{~m}$ are shown. 
The sharks were landed in Natal, measured in $\mathrm{cm} \mathrm{TL}$, dissected, and their stomachs removed and stored, frozen, for later identification of the prey items in the laboratory. Prey organisms in the stomach contents were identified to the lowest possible taxon. A prey taxon was called a "food item", and a unit of prey organism a "prey". The number of prey of each food item, the mantle length for cephalopods ( $\mathrm{cm} \mathrm{ML),} \mathrm{total} \mathrm{length} \mathrm{for} \mathrm{other} \mathrm{organisms}(\mathrm{cm} \mathrm{TL})$, and wet weight $(\mathrm{W}, \mathrm{g})$ of each prey in each stomach were recorded. A richness prey curve was computed to infer whether the stomachs sampled were sufficient to obtain the food spectrum of both predators.

The importance of each food item in the diet was obtained by the Index of Relative Importance (IRI) (PINKAS et al., 1971; CORTÉS, 1997), modified to weight in the pooled samples of the species, as follows: $\mathrm{IRI}_{\mathrm{i}}=\% \mathrm{FO}_{\mathrm{i}} \times\left(\% \mathrm{~N}_{\mathrm{i}} \times \% \mathrm{~W}_{\mathrm{i}}\right)$, where $\% \mathrm{FO}_{\mathrm{i}}$ is the relative frequency of occurrence of each food item; $\% \mathrm{~N}_{\mathrm{i}}$ is the proportion in prey number of each item in the total food; and $\% \mathrm{~W}_{\mathrm{i}}$ is the proportion by weight of each item in the total food.

The niche overlap between predators was determined by the Schoener Index (T), (SCHOENER, 1970): $\mathrm{T}=1-0.5 \sum\left|\mathrm{Px}_{\mathrm{i}}-\mathrm{Py}_{\mathrm{i}}\right|$, where, $\mathrm{Px}_{\mathrm{i}}$ is the proportion in frequence of occurrence of the food item "i" in the diet of the predator " $\mathrm{x}$ ", and $\mathrm{Py}_{\mathrm{i}}$ is the proportion in frequence of occurrence of the food item "i" in the diet of the predator "y". Significant biological similarity was considered to exist when $\mathrm{T} \geq 0.6$ (SCRIMGEOUR; WINTERBOURN, 1987).

\section{RESULTS}

The total length of 425 specimens of $C$. signatus and 98 specimens of $S$. lewini, of both sexes, is shown in Figure 2. If the size at sexual maturity for females of $C$. signatus is estimated at between 200 and $205 \mathrm{~cm}$ TL, while that for males is between 185 and $190 \mathrm{~cm}$ TL (HAZIN et al., 2000), then the majority of specimens were considered sexually immature. Sexual maturity of $S$. lewini ranges between 180 and $200 \mathrm{~cm}$ TL for males, and between 180 and $240 \mathrm{~cm}$ TL for females (HAZIN et al., 2000), hence, as with $C$. signatus, the majority of specimens of $S$. lewini had not reached sexual maturity.

The richness of food items for $C$. signatus did not attain stability even though 215 stomachs were analyzed (Fig. 3). There was no tendency to stabilization for $S$. lewini either, but in this case this may have been due to the small number of stomachs analyzed.

Teleosts and cephalopods were the main prey items for both predators observed in the IRI ranking, nevertheless, when more specific groups are taken into account, some differences and similarities are to be observed. A total of 215 stomachs of $C$. signatus contained some food, 29 taxa of which were identified, including 10 species of fish, 14 cephalopods, 3 crustaceans, 1 tunicate, and 1 sea bird. Among the fish noteworthy predation occurred upon small pelagic species such as Diaphus sp., Acanthurus sp., Howella sp., and Brama caribbea (Table 1). Also important were large pelagic fish such as Katsuwonus pelamis, Thunnus albacares and Xiphias gladius. The cephalopods Histioteuthis sp., Ommastrephes bartramii, Octopoteuthis sp., Vampyroteuthis infernalis and Cranchiidae were the main representatives in the diet by IRI ranking. The deep water shrimp Heterocarpus ensifer was the main crustacean item. The presence of salps and the seabird Puffinus gravis was observed on two ocasions.

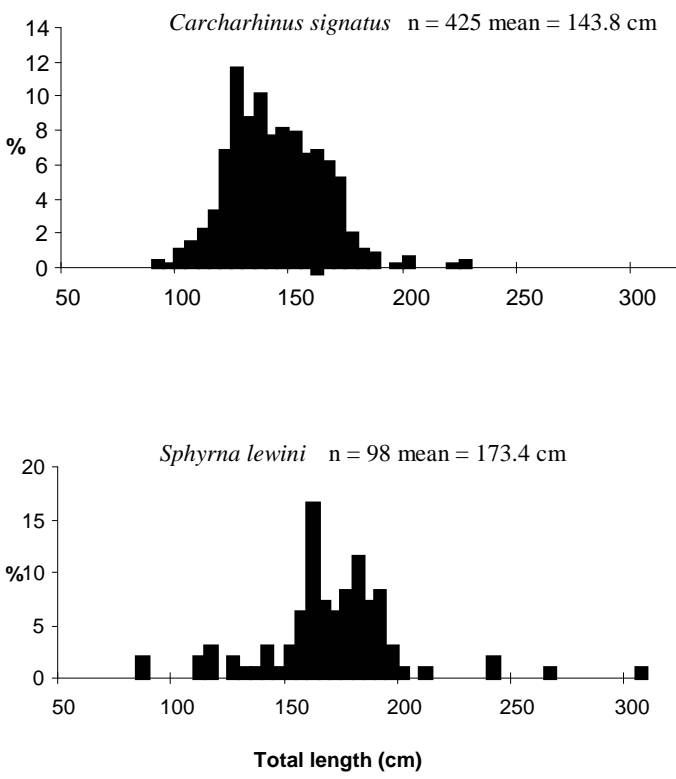

Fig. 2. Length distributions for Carcharhinus signatus and Sphyrna lewini from seamounts off northeastern Brazil.

In the stomachs of 50 of the 98 S. lewini, there was some food. 27 taxa were observed: 10 species of fish, 15 cephalopods and 2 crustaceans (Table 1). The main fish prey items were reef dwelling species, such as Lutjanus buccanella, Sparisoma viride, Monacanthidae, Muraenidae, but also pelagic predators such as Sphyraena barracuda, Caranx sp., Ruvettus pretiosus, and Thunnus obesus. The squid Histioteuthis sp. was the main prey item, followed by Ommastrephes bartramii and Cranchiidae. The similarity of the diets of $C$. signatus and S. lewini, measured by the Schoener Index (T), showed that both species share the same prey spectrum, with a significant degree of similarity $(\mathrm{T}=0.75)$. 

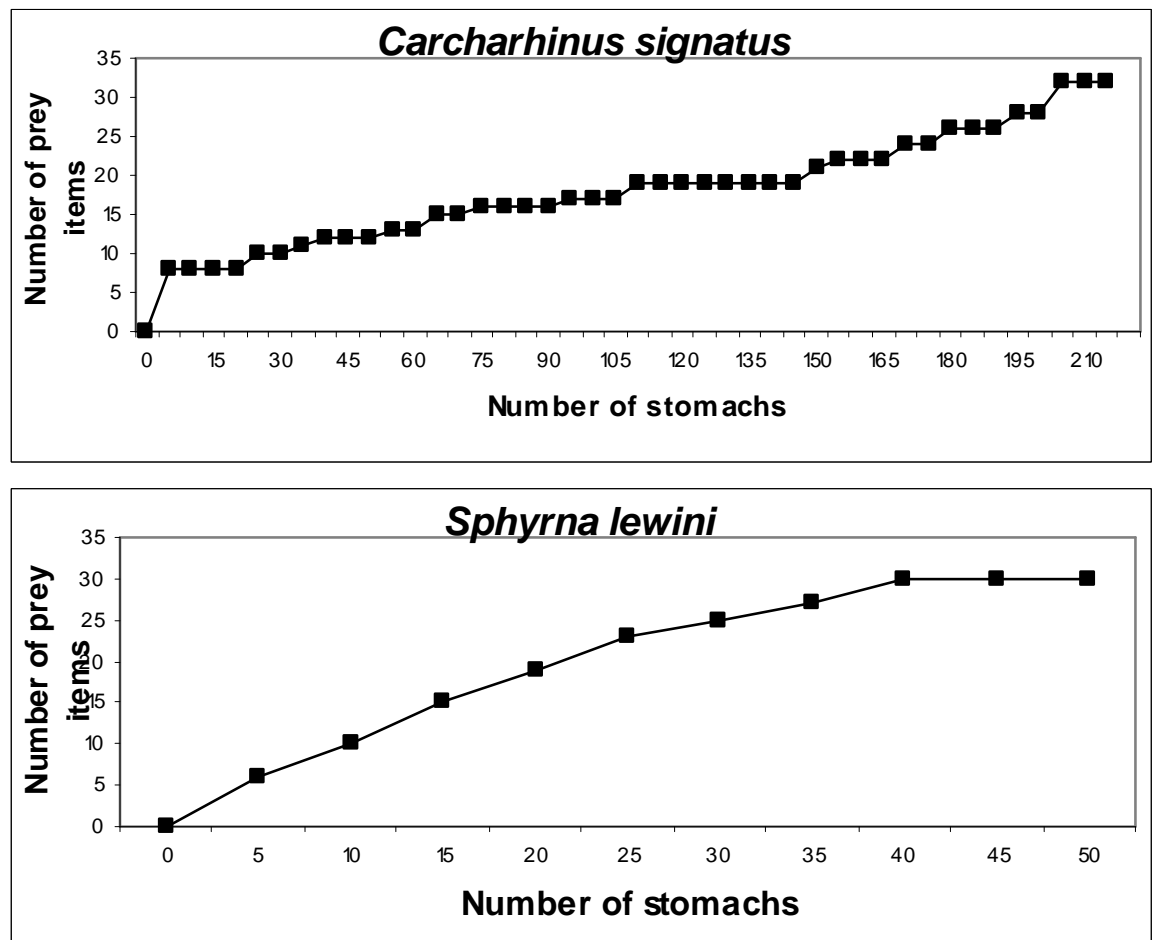

Fig. 3. Richness prey curve for Carcharhinus signatus and Sphyrna lewini from seamounts off northeastern Brazil.

Table 1. Number, weight and frequence of occurrence of food items, and IRI ranking (first to tenth) for Sphyrna lewini and Carcharhinus signatus of oceanic banks off northeastern Brazil.

\begin{tabular}{|c|c|c|c|c|c|c|c|c|c|c|c|c|c|c|}
\hline \multirow[b]{4}{*}{ Prey items } & \multicolumn{7}{|c|}{ Sphyrna lewini } & \multicolumn{7}{|c|}{ "Carcharhinus signatus } \\
\hline & \multicolumn{7}{|c|}{ Stomachs containing food: $\mathbf{5 0}$} & \multicolumn{7}{|c|}{ Stomachs containing food: 215} \\
\hline & \multicolumn{7}{|c|}{ Empty stomachs: 48} & \multicolumn{7}{|c|}{ Empty stomachs: 210} \\
\hline & $\mathbf{N}$ & $\% \mathbf{N}$ & $\mathbf{W}$ & $\% \mathbf{W}$ & FO & $\% \mathrm{FO}$ & IRI & $\mathbf{N}$ & $\% \mathbf{N}$ & $\mathbf{W}$ & $\% \mathbf{W}$ & FO & $\%$ FO & IRI \\
\hline Acanthurus sp. & & & & & & & & 3 & 0.89 & 2 & 0.02 & 1 & 0.47 & \\
\hline Brama caribbea & & & & & & & & 9 & 2.68 & 498 & 4.13 & 7 & 3.26 & 10 \\
\hline Diaphus sp. & & & & & & & & 1 & 0.30 & 9 & 0.07 & 1 & 0.47 & \\
\hline Caranx sp. & 2 & 0.28 & 800 & 3.26 & 2 & 4 & & & & & & & & \\
\hline Howella sp. & & & & & & & & 4 & 1.19 & 27 & 0.22 & 1 & 0.47 & \\
\hline Katsuwonus pelamis & & & & & & & & 4 & 1.19 & 1726 & 14.31 & 3 & 1.40 & \\
\hline Lutjanus bucanella & 1 & 0.14 & 6620 & 26.97 & 1 & 2 & 6 & & & & & & & \\
\hline Monacanthidae & 1 & 0.14 & 390 & 1.59 & 1 & 2 & & & & & & & & \\
\hline Muraenidae & 1 & 0.14 & 4664 & 19.00 & 1 & 2 & 7 & & & & & & & \\
\hline Ruvettus pretiosus & 2 & 0.28 & 3481 & 14.18 & 2 & 4 & 5 & & & & & & & \\
\hline
\end{tabular}


Table 1. Cont.

\begin{tabular}{|c|c|c|c|c|c|c|c|c|c|c|c|c|c|c|}
\hline \multirow[b]{4}{*}{ Prey items } & \multicolumn{7}{|c|}{ Sphyrna lewini } & \multicolumn{7}{|c|}{ Carcharhinus signatus } \\
\hline & \multicolumn{7}{|c|}{ Stomachs containing food: 50} & \multicolumn{7}{|c|}{ Stomachs containing food: 215} \\
\hline & \multicolumn{7}{|c|}{ Empty stomachs: 48} & \multicolumn{7}{|c|}{ Empty stomachs: 210} \\
\hline & $\mathbf{N}$ & $\% \mathbf{N}$ & $\mathbf{W}$ & $\% \mathrm{~W}$ & FO & $\% \mathrm{FO}$ & IRI & $\mathbf{N}$ & $\% \mathbf{N}$ & $\mathbf{W}$ & $\% \mathrm{~W}$ & FO & $\% \mathrm{FO}$ & IRI \\
\hline Serranidae & & & & & & & & 1 & 0.30 & 300 & 2.49 & 1 & 0.47 & \\
\hline Sparissoma viride & 4 & 0.56 & 321 & 1.31 & 1 & 2 & & & & & & & & \\
\hline Sphyraena barracuda & 1 & 0.14 & 1200 & 4.89 & 1 & 2 & & & & & & & & \\
\hline Teleostei & 54 & 7.56 & 1697 & 6.91 & 25 & 50 & 2 & 11 & 3.27 & 2659 & 22.04 & 64 & 29.77 & 1 \\
\hline Thunnus albacares & & & & & & & & 5 & 1.49 & 3279 & 27.18 & 2 & 0.93 & 9 \\
\hline Thunnus obesus & 1 & 0.14 & 2810 & 11.45 & 1 & 2 & 10 & & & & & & & \\
\hline Xiphias gladius & & & & & & & & 2 & 0.60 & 1270 & 10.53 & 2 & 0.93 & \\
\hline FISHES & 69 & 9.66 & 22999 & 93.69 & & & & 43 & 12.8 & 9941 & 82.42 & & & \\
\hline Cephalopoda & 9 & 1.26 & 159 & 0.65 & 7 & 14 & 9 & 24 & 7.14 & 600 & 4.97 & 15 & 6.98 & 2 \\
\hline Chiroteuthis sp. & 10 & 0.28 & 12 & 0.05 & 1 & 2 & & 7 & 0.89 & 14 & 0.12 & 3 & 1.40 & \\
\hline Cranchiidae & 28 & 2.94 & 246 & 1 & 11 & 22 & 4 & 17 & 3.57 & 80 & 0.66 & 10 & 4.65 & \\
\hline Halyphron atlanticus & 1 & 0.14 & 4 & 0.02 & 1 & 2 & & & & & & & & \\
\hline Histioteuthis spp. & 139 & 18.35 & 680 & 2.77 & 21 & 42 & 1 & 35 & 9.23 & 203 & 1.68 & 16 & 7.44 & 3 \\
\hline Hyaloteuthis pelagica & 33 & 4.62 & 11 & 0.04 & 1 & 2 & & 7 & 2.08 & 26 & 0.22 & 3 & 1.40 & \\
\hline Japetella diaphana & 1 & 0.14 & & & 1 & 2 & & & & & & & & \\
\hline Octopodidae & 8 & 0.84 & 2 & 0.01 & 2 & 4 & & 2 & 0.30 & 2 & 0.02 & 1 & 0.47 & \\
\hline Octopoteuthis sp. & 4 & 0.14 & 2 & 0.01 & 1 & 2 & & 33 & 6.25 & 193 & 1.60 & 12 & 5.58 & 7 \\
\hline Acanthurus sp. & & & & & & & & 3 & 0.89 & 2 & 0.02 & 1 & 0.47 & \\
\hline Brama caribbea & & & & & & & & 9 & 2.68 & 498 & 4.13 & 7 & 3.26 & 10 \\
\hline Diaphus sp. & & & & & & & & 1 & 0.30 & 9 & 0.07 & 1 & 0.47 & \\
\hline Caranx sp. & 2 & 0.28 & 800 & 3.26 & 2 & 4 & & & & & & & & \\
\hline Howella sp. & & & & & & & & 4 & 1.19 & 27 & 0.22 & 1 & 0.47 & \\
\hline Katsuwonus pelamis & & & & & & & & 4 & 1.19 & 1726 & 14.31 & 3 & 1.40 & \\
\hline Lutjanus bucanella & 1 & 0.14 & 6620 & 26.97 & 1 & 2 & 6 & & & & & & & \\
\hline Monacanthidae & 1 & 0.14 & 390 & 1.59 & 1 & 2 & & & & & & & & \\
\hline Muraenidae & 1 & 0.14 & 4664 & 19.00 & 1 & 2 & 7 & & & & & & & \\
\hline Ruvettus pretiosus & 2 & 0.28 & 3481 & 14.18 & 2 & 4 & 5 & & & & & & & \\
\hline Scombridae & 2 & 0.28 & 1016 & 4.14 & 2 & 4 & & 3 & 0.89 & 171 & 1.42 & 3 & 1.40 & \\
\hline Serranidae & & & & & & & & 1 & 0.30 & 300 & 2.49 & 1 & 0.47 & \\
\hline Sparissoma viride & 4 & 0.56 & 321 & 1.31 & 1 & 2 & & & & & & & & \\
\hline Sphyraena barracuda & 1 & 0.14 & 1200 & 4.89 & 1 & 2 & & & & & & & & \\
\hline Teleostei & 54 & 7.56 & 1697 & 6.91 & 25 & 50 & 2 & 11 & 3.27 & 2659 & 22.04 & 64 & 29.77 & 1 \\
\hline
\end{tabular}


Table 1. Cont.

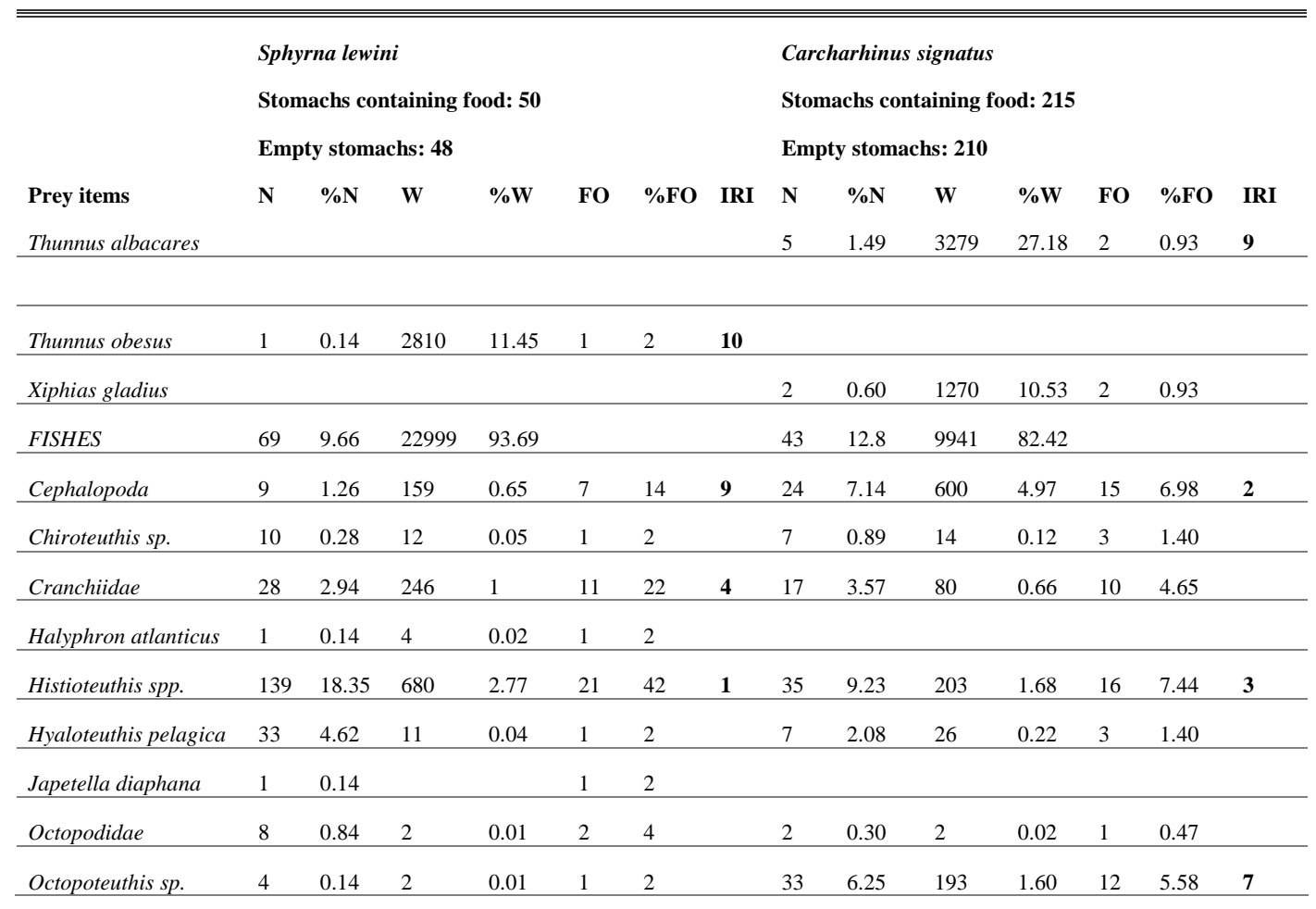

\section{Discussion}

The concentration of predators around seamounts is evident by reason of the large numbers of reef and pelagic fishes that occur there, as also of epi and mesopelagic cephalopods, which are diverse and abundant food resources for other predators too (MORATO et al., 2008). As a consequence, the predators become the target of a localized and specific fishery fleet, as in the case of the fishing for S. lewini and $C$. signatus around the northeastern Brazilian seamounts.

The presence of specimens of reef and pelagic fish in the diet of $S$. lewini shows that this species searches for its prey close to the reefs as much as in the adjacent pelagic environment, suggesting that there is a constant displacement between shallow and deep waters. Nevertheless, all the cephalopods preyed upon are oceanic species, particularly Histioteuthis sp., which is a common species in shelf break and oceanic waters (ROPER; YOUNG, 1975). Cephalopods like Chiroteuthis sp. and Vampyroteuthis infernalis, and the shrimp Heterocarpus ensifer inhabit deep waters, beyond $300 \mathrm{~m}$, which means that $S$. lewini make incursions into deep waters, descending to the bed to feed upon deep-dwelling prey. Smale and Cliff (1998) observed that adults of S. lewini from South Africa consumed more oceanic than neritic cephalopods.
Analysis of the diet of small and coastal specimens of $S$. lewini from Hawaii showed that the most common prey items were alpheid shrimps and two species of goby, the most abundant benthic local megafauna (BUSH, 2003). In the Gulf of California (Mexico), dark squid (Loliolopsis diomedeae) and the bony fish Carangidae and Gerreidae were the main prey items among the 87 identified (TORRES-ROJAS et al., 2006). In South Africa, 60 teleost species were found in the stomachs, Trichiuridae, Pomadasydae and Sparidae being the most representative fish, but coastal cephalopods and sharks of the family Scyliorhinidae were also found (BRUYN et al., 2005).

In the case of $C$. signatus, there is a preference for migrant squids such as Histioteuthis sp., Ommastrephes bartramii, Ornithoteuthis antillarum, and also Vampyroteuthis infernalis. The deep water shrimp Heterocarpus ensifer is the main prey among crustaceans, as was also observed for S. lewini. On the other hand, fish preyed upon by $C$. signatus belong more to the pelagic than to the reef habitat, which means that the predator searches for prey in the pelagic waters around the oceanic banks, and occasionally comes near to the shelf break of the banks. Patokina and Litvinov (2005) found shelf break species such as Trichiurus sp. and Octopoteuthis sicula in Sierra Leone waters in the stomachs of 11 individuals of $C$. signatus. 
The feeding strategy of both predators in the region seems to bring them close to seamounts to prey upon the reef and bentho-pelagic fishes and migrant cephalopods commonly found in shelf breaks, and also upon deep-water crustaceans such as the penaeid Heterocarpus ensifer. According to Cortés (1999), both predators have very similar trophic levels, 4.2 for C. signatus, and 4.1 for $S$. lewini, that is evident at these seamounts, because both predators have a preference for shelf breaks when they are juveniles and adults involved. The high prey richness of the diets suggests that these species belong to very extensive food webs at the seamounts off Brazil and reinforce the idea that these sharks occupy upper trophic levels, as proposed by Cortés (1999).

Carcharhinus signatus is considered to be globally vulnerable on the basis of significant population declines throughout its Western Atlantic range, and S. lewini is classified as Lower Risk - near threatened (LR/nt) on the IUCN Red List 2004. As observed by Worm et al. (2003), the seamounts in the present study may be an example of concentration of biodiversity, or hotspots in open waters, with features that enhance local production and consequently maintain an important concentration of commercial sharks. Seamounts shallower than $400 \mathrm{~m}$ depth show significant aggregation effects (MORATO et al., 2008) and a special effort should be made to ensure a sustainable fishery in the vicinities of these habitats. In this way, due to the concentration for feeding of both predators in the seamounts, intense fisheries should be monitored to avoid localised depletions.

\section{ACKNOWLEDGEMENTS}

The present research was funded by the Ministério do Meio Ambiente-MMA, Secretaria da Comissão Interministerial para os Recursos do MarSECIRM within the scope of the Programa de Avaliação do Potencial Sustentável dos Recursos Vivos - REVIZEE. The authors are grateful to Norte Pesca S.A., CEPENE/IBAMA and to the Conselho Nacional de Desenvolvimento Científico e Tecnológico- CNPq for Scholarships and Research Grants provided during the research (Proc: 301048/83Oc and 301484/92-9). The authors also wish to thank the crew of the N.Pq. Riobaldo (IBAMA) and the several students of the UFRPE who took part in the cruises to help with data collection.

\section{REFERENCES}

BUSH, A. Diet and diel feeding periodicity of juvenile scalloped hammerhead sharks, Sphyrna lewini, in Kaneohe Bay, Oahu, Hawaii. Env. Biol. Fishes, v. 67, p. 1 - 11, 2003.

BUSH, A; HOLLAND, K. Food limitation in a nursery area: estimates of daily ration in juvenile scalloped hammerheads, Sphyrna lewini (Griffith \& Smith, 1834) in
Kaneohe Bay, Oahu, Hawaii. J. exp. mar. Biol. Ecol., v. 278, p. $157-178,2002$.

BRUYN, P.; DUDLEY, S. F. J.; CLIFF, G.; SMALE, M. J. Sharks caught in the protective gill nets off KwazuluNatal, South Africa. 11. The scalloped hammerhead shark Sphyrna lewini (Griffith and Smith). Afr. J. mar. Sci., v. 27, n.3, p. 517 - 528, 2005.

CLARKE, T. A. The ecology of the scalloped hammerhead shark, Sphyrna lewini, in Hawaii. Pacific Sci., v. 25, p. 133 $-145,1971$.

COMPAGNO, L. J. V. FAO Species catalogue. Vol. 4. Sharks of the world. An annotated and illustrated catalogue of shark species known to date. Part 2. Carcharhiniformes. FAO Fish. Synop., v. 125, n. 4, p. 251 - 655, 1984.

CORTÉS, E. A. critical review of methods of studying fish feeding based on analysis of stomach contents: application to elasmobranch fishes. Can. J. Fish. aquat. Sci., v. 54, p. $726-738,1997$.

CORTÉS, E. Standardized diet compositions and trophic levels of sharks. ICES J. mar. Sci., v. 56, p. 707 - 717, 1999.

FERREIRA, A. G.; FARIA, V. V.; CARVALHO, C. E. V.; LESSA, R. P. T.; SANTANA, F. M. Total mercury in the night shark, Carcharhinus signatus in the western equatorial Atlantic. Braz. Arch. Biol. Tech., v. 47, n. 4: $629-634,2004$.

GADIG, O. B. F.; MOREIRA JÚNIOR, W. Tubarões da Costa Brasileira. Leopoldianum, v. 18, n. 52, p. 111$119,1992$.

HAZIN, F. H. V.; COUTO, A. A.; KIHARA, K.; OTSUKA, K.; ISHINO, M. Distribution and abundance of pelagic sharks in the southwestern equatorial Atl. J. Tokio Univ. Fish., v. 77, n. 1, p. $51-64,1990$.

HAZIN, F. H. V.; LUCENA, F. M.; SOUZA, T. S. A. L.; BOECKMANN, C. E.; BROADHURST, M. K.; MENNI, R. C. Maturation of the night shark, Carcharhinus signatus, in the Southwestern Equatorial Atlantic ocean. Bull. mar. Sci., v. 66, n. 1, p. 173 - $185,2000$.

HAZIN, F. H. V.; FISCHER, A.; BROADHURST, M. Aspects of reproductive biology of the scalloped hammerhead shark, Sphyrna lewini, off northeastern Brazil. Env. Biol. Fishes, v. 61, p. $151-159,2001$.

MENNI, R. C.; HAZIN, F. H. V.; LESSA, R. P. Occurrence of the night shark Carcharhinus signatus and the pelagic stingray Dasyatis violacea off northeastern Brazil. Neotrópica v. 41, n. 105-106, p. 105 - 110, 1995.

MORATO, T.; VARKEY, D. A.; DAMASO, C.; MACHETE, M.; SANTOS, M.; PRIETO, R.; SANTOS, R. S.; PITCHER, T. Evidence of a seamount effect on aggregating visitors. Mar. Ecol. Prog. Ser., v. 357, p. $23-$ 32, 2008.

OLIVEIRA, G. M.; EVANGELISTA, J. E. V.; FERREIRA, B. P. Considerações sobre a biologia e a pesca no Arquipélago dos Penedos São Pedro e São Paulo. Bolm Técnico-Cient. CEPENE, v. 5, n. 1, p. 31 - 52, 1997.

PATOKINA, F. A.; LITVINOV, F. F. Food composition and distribution of elasmobranches on the shelf and upper slope of the Eastern Central Atlantic. ICES CM 2005/N: 26, 2005.

PINKAS, L.; OLIPHANT, M. S.; IVERSON, I. L. K. Food habits of albacore, bluefin tuna, and bonito in Californian waters. Fish Bull., Dept Fish and Game, California, , v. 152, $105 \mathrm{p}, 1971$. 
ROPER, C. F. E.; YOUNG, R. E. Vertical distribution of pelagic cephalopods. Smithson. Contrib. Zool., v. 209, p. 1 - 51, 1975.

SANTANA, F. M.; LESSA, R. Age determination and growth of the night shark (Carcharhinus signatus) off the northeastern Brazilian coast. Fish. Bull., v. 102, p. 156 $167,2004$.

SANTANA, F. M.; LESSA, R.; CARLSON, J. Carcharhinus signatus. In: 2006 IUCN Red List of Threatened Species. IUCN, 2006. < www.iucnredlist.org>.

SCHOENER, T. W. Nonsynchronous spatial overlap of lizards in patchy habitats. Ecology, v. 51, p. 408 - 418, 1970.

SCRIMGEOUR, G. L.; WINTERBOURN, M. J. Diet, food resource partitioning and feeding periodicity of two riffledwelling fish species in a New Zealand river. J. Fish Biol., v. 31 , p. 309 - 324, 1987.

SMALE, M. J.; CLIFF, G. Cephalopods in the diets of four shark species (Galeocerdo cuvier, Sphyrna lewini, Sphyrna zygaena, and S. mokarran) from Kwazulu-Natal, South Africa. S. Afr. J. mar. Sci., v. 20, p. 241 - 253, 1998.
SOTO, J. M. Annotated systematic checklist and bibliography of the coastal and oceanic fauna of Brazil. I - Sharks. Mare Magnum, v. 1, n. 1, p. 51 - 120, 2001.

TORRES-ROJAS, Y.; HERNANDEZ-HERRERA, A.; GALVAN-MAGAÑA, F. Feeding habits of the scalloped hammerhead shark, Sphyrna lewini, in Mazatlán waters, southern Gulf of California, Mexico. Cybium, v. 30, n.4, p. $85-90,2006$.

VASKE JUNIOR, T.; LESSA, R. P.; NÓBREGA, M. F.; MONTEALEGRE-QUIJANO, S.; SANTANA, F. M.; BEZERRA JR. J. L. A checklist of fishes from Saint Peter and Saint Paul Archipelago, Brazil. J. appl. Ichth., v. 21, n.1, p. 75-79, 2005.

WORM, B.; LOTZE, H. K.; MYERS, R. A. Predator diversity hotspots in the blue ocean. PNAS, v. 100 , n. 17 , p. $9884-$ 9888, 2003.

(Manuscript received 10 June 2008; revised 01 July 2008; accepted 15 August 2008) 